\title{
Recombinant Property in East European Capitalism $^{1}$
}

\author{
David Stark \\ Cornell University
}

\begin{abstract}
Recombinant property is a form of organizational hedging in which actors respond to uncertainty by diversifying assets, redefining and recombining resources. It is an attempt to hold resources that can be justified by more than one legitimating principle. Property transformation in postsocialist Hungary involves the decentralized reorganization of assets and the centralized management of liabilities. Together they blur the boundaries of public and private, the boundaries of enterprises, and the boundedness of justificatory principles. Enterprise-level field research, data on the ownership structure of Hungary's 220 largest enterprises and banks, and an examination of the government's recent debt consolidation programs suggest the emergence of a distinctively East European capitalism that will differ as much from West European capitalisms as do contemporary East Asian variants.
\end{abstract}

\section{INTRODUCTION}

Sociology began as a science of transition, founded at our century's turn on studies of the epochal shifts from tradition to modernity, rural to urban society, gemeinschaft to gesellschaft, feudalism to capitalism, and mechanical to organic solidarity. For the founders of sociology, the crisis

\footnotetext{
${ }^{1}$ Research for this paper was conducted while the author was a visiting fellow at the Institute for Advanced Study/Collegium Budapest and was supported by grants from the National Science Foundation, IRIS (Institutional Reform and the Informal Sector), and the Project on Corporate Governance of the World Bank/Central European University. My thanks to Luc Boltanski, Ronald Breiger, Rogers Brubaker, László Bruszt, Ellen Comisso, Paul DiMaggio, Neil Fligstein, Geoff Fougere, István Gábor, Gernot Grabher, Szabolcs Kemény, János Kornai, János Lukács, Peter Murrell, László Neumann, Claus Offe, Kent Redding, Ákos Róna-Tas, Iván Szelényi, Andrew Walder, Pamela Walters, and especially Monique Djokic Stark for their criticisms of an earlier draft. Correspondence may be addressed to David Stark, Department of Sociology, Uris Hall, Cornell University, Ithaca, New York 14853.
}

(c) 1996 by The University of Chicago. All rights reserved.

0002-9602/96/10104-0006\$01.50 
besetting European societies at the end of the 19th century was diagnosed as a normative and institutional vacuum. The old order regulated by tradition had passed, but a new moral order had not yet been established.

During our own fin de siècle, not the crumbling of traditional structures but the collapse of communism gives new life to the transition problematic (Nee 1989; Lipset 1990; and see Alexander [1994] for an extended critical discussion). Within that problematic, the present is studied as an approximation of a designated future (Blanchard, Froot, and Sachs 1994), risking an underlying teleology in which concepts are driven by hypostasized end-states. In the framework of transitology, the transitional present is a period of dislocation as society undergoes the passage through a liminal state suspended between one social order and another (Bunce and Csanadi 1993), each conceived as a stable equilibrium organized around a coherent and more or less unitary logic.

But is ours still the century of transition? And is that model of social change, so formative in the launching of sociology, still adequate for understanding the momentous changes in contemporary Eastern Europe?

Difficult to assimilate within the transition problematic are the numerous studies from Eastern Europe documenting parallel and contradictory logics in which ordinary citizens were already experiencing, for a decade prior to 1989 , a social world in which various domains were not integrated coherently (Gábor 1979, 1986; Szelényi 1988; Stark 1986, 1989; Róna-Tas 1994). ${ }^{2}$ Through survey research and ethnographic studies, researchers have identified a multiplicity of social relations that did not conform to officially prescribed hierarchical patterns. These relations of reciprocity and marketlike transactions were widespread inside the socialist sector as well as in the "second economy" and stemmed from the contradictions of attempting to "scientifically manage" an entire national economy. At the shop-floor level, shortages and supply bottlenecks led to bargaining between supervisors and informal groups; at the managerial level, the task of meeting plan targets required a dense network of informal ties that cut across enterprises and local organizations; and the allocative distortions of central planning produced the conditions for the predominantly part-time entrepreneurship of the second economies that differed in scope, density of network connections, and conditions of legality across the region (Gábor 1979; Kornai 1980; Sabel and Stark 1982; Szelényi 1988).

The existence of parallel structures (however contradictory and fragmentary) in these informal and interfirm networks that "got the job

${ }^{2}$ East European scholars have long argued that social change is a transformational reshaping of enduring structures exhibiting multiplicity rather than uniformity (Konrad and Szelényi 1979; Szücs 1985; Staniszkis 1993; Szelényi 1994). 
done" means that the collapse of the formal structures of the socialist regime does not result in an institutional vacuum. Instead, we find the persistence of routines and practices, organizational forms and social ties, that can become assets, resources, and the basis for credible commitments and coordinated actions in the postsocialist period (Bourdieu 1990; Nelson and Winter 1982). In short, in place of disorientation, we find the metamorphosis of sub-rosa organizational forms and the activation of preexisting networks of affiliation.

If, by the 1980s, the societies of Eastern Europe were decidedly not systems organized around a single logic, they are not likely in the postsocialist epoch to become, any more or less than our own, societies with a single system identity. Change, even fundamental change, of the social world is not the passage from one order to another but rearrangements in the patterns of how multiple orders are interwoven. Organizational innovation in this view is not replacement but recombination (Schumpeter 1934).

Thus, we examine how actors in the postsocialist context are rebuilding organizations and institutions not on the ruins but with the ruins of communism as they redeploy available resources in response to their immediate practical dilemmas. Such a conception of path dependence does not condemn actors to repetition or retrogression, ${ }^{3}$ for it is through adjusting to new uncertainties by improvising on practiced routines that new organizational forms emerge (Nelson and Winter 1982; White 1993; Kogut and Zander 1992; Sabel and Zeitlin 1996). The analysis that follows emphasizes the organizational reflexivity that is possible when actors maneuver across a multiplicity of legitimating principles and strategically exploit ambiguities in the polyphony of accounts of work, value, and justice that compose modern society (Boltanski and Thevenot 1991; White 1992; Stark 1990; Padgett and Ansell 1993; Breiger 1995).

\section{A New Type of Mixed Economy?}

This article examines the recombinatory logic of organizational innovation in the restructuring of property relations in Hungary. It asks, Are recombinant processes resulting in a new type of mixed economy as a distinctively East European capitalism?

For more than 30 years, policy analysts in Eastern Europe debated the "correct mix of plan and market" (Stark and Nee 1989). By the

\footnotetext{
${ }^{3}$ See, by contrast, Burawoy and Krotov's account of change as retrogression: "Our case study suggests that with the withering away of the party state the Soviet economy, far from collapsing or transforming itself, has assumed an exaggerated version of its former self" (1992, p. 34).
} 
mid-1980s in Hungary, the debate had shifted to the correct mix of "public and private property" as the earlier sacrosanct status of collective property eroded with the growth of the second economy. It was thus, in the waning years of state socialism, that Gábor (1986) and Szelényi (1988) coined the term "socialist mixed economy" to designate the new economic configuration. ${ }^{4}$ Meanwhile, Stark (1989, p. 168), amplifying Gábor's call to acknowledge a mixed economy "as a viable hybrid form and not as inherently unstable and necessarily transitional," questioned nonetheless whether the concept of mixed economy was adequate to grasp the emergent phenomena of late socialism. On the basis of field research on "intrapreneurial" subcontracting units in Hungarian firms, I argued that aspects of emergent private property were not respecting the boundaries of the second economy but were being fused with public ownership inside the socialist firm resulting in a "diversification of property forms." Identifying "hybrid mixtures of public ownership and private initiative" (Stark 1989, pp. 167-68) I argued that, instead of a mixed economy with well-bounded public and private sectors, analysis should begin to address the growing plurality of "mixed property forms" that transgressed and blurred traditional property boundaries.

Scholars of economic reforms in China subsequently developed related concepts to analyze the fiscal reforms reshaping incentives among local governments giving rise to "township and village enterprises." Oi's (1992) concept of "local corporatism," Nee's (1992) "hybrid property," and Cui's (in press) notion of "moebius-strip ownership" each illuminated a particular facet of Chinese property reforms that supported the general conclusion that China's is not a simple mixed economy but a kaleidoscope of mixed public and private property forms.

Of special relevance to my concerns is Walder's (1994) insight that property reform should not be equated with privatization. Walder argues that "clarification of property rights" in the Chinese fiscal reforms can yield performance enhancing incentives even while maintaining "public ownership" without privatization. Our analysis of the Hungarian case also demonstrates that property transformation can occur without conventional privatization. ${ }^{5}$ The difference, however, is that property trans-

\footnotetext{
${ }^{4}$ Szelényi (1978) argued that "mixture" characterized both East and West: whereas a redistributive welfare state mitigates inequalities produced by markets under advanced capitalism, in state socialism subordinated marketlike institutions mitigate inequalities produced by the dominant redistributive mechanism. Elsewhere (Stark 1986) I labeled this analytic method "mirrored opposition" and used it to analyze differences between capitalist and socialist internal labor markets.

${ }^{5}$ In her analysis of "political capitalism" in Poland, Staniszkis (1991) similarly identifies "hybrid forms" of "undefined dual status" in a variety of leasing forms and cost-shifting arrangements through which nomenclatura companies enjoy the benefits of property transformation without privatization.
} 
formation in Hungary does not necessarily clarify property rights. As we shall see, the emerging new property forms in Hungary blur (1) the boundaries of public and private, (2) the organizational boundaries of enterprises, and (3) the boundedness of justificatory principles. To denote these processes of triple boundary blurring I adopt the term recombinant property.

Recombinant property is a form of organizational hedging, or portfolio management, in which actors respond to uncertainty in the organizational environment by diversifying their assets, redefining and recombining resources. It is an attempt to hold resources that can be justified or assessed by more than one standard of measure.

The distinctive variant of organizational hedging that is recombinant property in Hungary is produced in two simultaneous processes: Parallel to the decentralized reorganization of assets is the centralized management of liabilities. On the one hand, decentralized reorganization produces the crisscrossing lines of interenterprise ownership networks; on the other, debt consolidation transforms private debt into public liability. Although these two dimensions are discussed separately, their simultaneity gives distinctive shape to Hungarian property. The clash of competing ordering principles produces organizational diversity that can form a basis for greater adaptability but, at the same time, creates acute problems of accountability.

Data. - My arguments are based on data collected during an 11-month stay in Budapest in 1993-94. That research includes (1) field research in six Hungarian enterprises, ${ }^{6}(2)$ compilation of a data set on the ownership structure of Hungary's 200 largest corporations and top 25 banks, ${ }^{7}$ and (3) interviews with leading actors in banks, property agencies, political parties, and government ministries. ${ }^{8}$

${ }^{6}$ Three of these firms are among the 20 largest firms in Hungary and are at the core of Hungarian manufacturing in metallurgy, electronics, and rubber products. Three are small and medium-size firms in plastics, machining, and industrial engineering. This field research was conducted in collaboration with László Neumann and involved longitudinal analysis of the same firms in which we had earlier studied an organizational innovation of internal subcontracting inside the socialist enterprise (Stark 1986, 1989, 1990; Neumann 1989).

${ }^{7}$ These data were augmented by ownership data drawn from the files of some 800 firms under the portfolio management of the State Property Agency.

${ }^{8} \mathrm{~A}$ partial list of interviewees includes the former president of the National Bank; the former deputy-minister of the Ministry of Finance; executives of the four largest commercial banks and two leading investment banks; the former president of the State Holding Corporation; directors, advisors, and officials of the State Property Agency; senior officials of the World Bank's Hungarian Mission; the chief economic advisors of the two major liberal parties; the president of the Federation of Hungarian Trade Unions; and leading officials of the Hungarian Socialist Party (who later ascended to high-level positions in the new Socialist-Liberal coalition government). 


\section{PROPERTY TRANSFORMATION IN HUNGARY: THE POLICY DEBATE}

My point of departure is a question central to contemporary debates in Eastern Europe and the former Soviet Union: By what means can private property become the typical form of property relations in economies overwhelmingly dominated by state ownership of productive assets?

Much of that debate can be organized around two fundamental policy strategies. First, the institutionalization of private property can best be established by transferring assets from public to private hands. Despite differences in the specific methods designated for such privatization (e.g., sale vs. free distribution, etc.), the various proposals within this radical perspective share the assumption that the creation of a private sector begins with the existing state-owned enterprises, that is, the basic organizational units of the emergent market economy will be the preexisting but newly privatized enterprises.

The second policy strategy argues from the perspective of institutional (and specifically, evolutionary) economics that, although slower, the more reliable road to institutionalizing private property rests in the development of a class of private proprietors. Instead of transferring the assets of a given organizational unit from one ownership form to another, public policy should lower barriers to entry for small and medium scale, genuinely private ventures. This perspective typically looks to the existing second economy entrepreneurs as the basic organizational building block of an emergent market economy.

Recent evidence suggests that Hungary is adopting neither a big bang approach nor the policy prescriptions of evolutionary economics. Contrary to the optimistic scenarios of domestic politicians and Western economists who foresaw a rapid transfer of assets from state-owned enterprises to private ownership, the overwhelming bulk of the Hungarian economy remains state property. Two years after Prime Minister Jozsef Antall confidently announced that his new government would privatize more than $50 \%$ of state property by 1995 , the director of the Privatization Research Institute functioning alongside the State Property Agency (SPA) estimated that only about $3 \%$ of the state-owned productive capital has been privatized (Mellár 1992). According to a recent study commissioned by the World Bank (Pistor and Turkewitz 1994), by mid-1994 the SPA had only sold about $11 \%$ of the value of its original portfolio.

Contrary as well to the hopes of evolutionary economics, a considerable body of evidence now suggests that the second economy has not become a dynamic, legitimate private sector: Although the number of registered private ventures has skyrocketed, many are "dummy firms," tax evasion is pervasive, and many entrepreneurs (a majority in some categories) still 
engage in private ventures only as a second job (Laky 1992; Gábor 1994, 1996). And although employment is slowly increasing in the sector, most researchers agree that the proportion of unregistered work (for which the state receives no social security payments and the employee receives no benefits) is increasing faster (Kornai 1992, p. 13).

These tendencies together with new forms of corruption, extortion, and exploitation have prompted one researcher to label the transition as one "from second economy to informal economy" arguing that it is now, under these new conditions, that Latin American comparisons are more applicable to the Hungarian setting (Sik 1992). When private entrepreneurs look to government policy, they see only burdensome taxation, lack of credits, virtually no programs to encourage regional or local development, and inordinate delays in payments for orders delivered to publicsector firms (Webster 1992; Kornai 1992). Through violations of tax codes, off-the-books payments to workers, and reluctance to engage in capital investment, much of the private sector is responding in kind (Gábor 1996). Such government policies and private-sector responses are clearly not a recipe for the development of a legitimate private sector as a dynamic engine of economic growth.

\section{THE DECENTRALIZED REORGANIZATION OF ASSETS}

Although they fail to correspond to the policy prescriptions of either big bang or evolutionary economics, significant property transformations are taking place in Hungary. Since 1989, there has been an explosion of new economic units. In table 1 , we see that

1. the number of state enterprises declined by about $60 \%$ from the end of 1988 to the middle of 1994;

2. the number of incorporated shareholding companies (részvéntársaság or RT) increased by more than 20-fold (from 116 to 2,679); and

3. the number of limited liability companies (korlátolt felelösségü társaság or KFT) increased most dramatically from only 450 units in 1988 to over 79,000 by the middle of 1994 .

Table 1 clearly indicates the sudden proliferation of new units in the Hungarian economy. But does the table provide a reliable map of property relations in contemporary Hungary? No, at least not if the data are forced into the dichotomous public/private categories that structure the discussion about property transformation in the postsocialist countries. As we shall see, actors within the large formerly state firms are transforming property relations at the enterprise level. The results, however, 


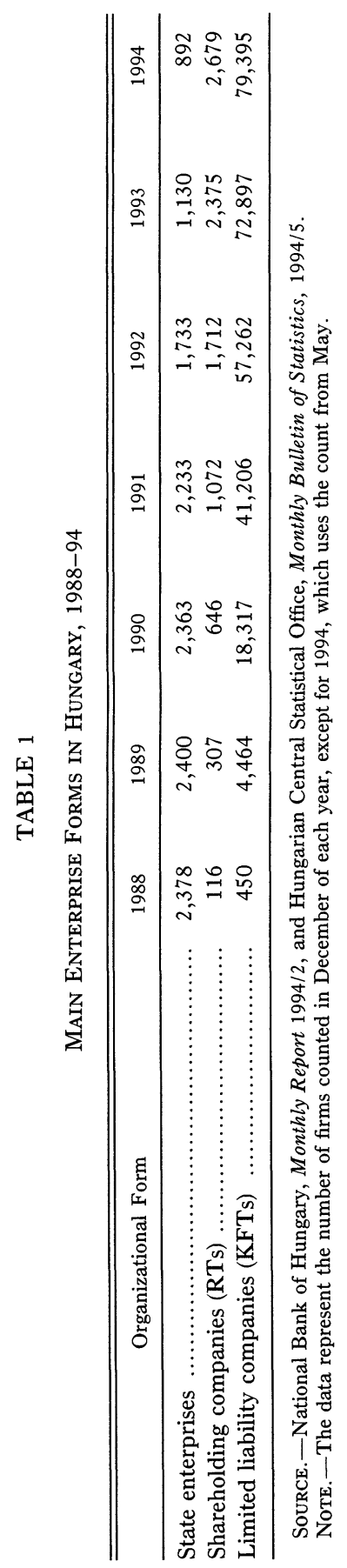


are not well-defined rights of private property, yet neither are they a continuation or reproduction of old forms of state ownership.

\section{New Forms of State Ownership}

Take first the shareholding companies (RTs) on line 2 of the table. Some of these corporations are private ventures newly established after the "system change." But many are the legal successors of the state-owned enterprises that would have been enumerated in the previous year on line 1 of the table. Through a mandatory process of "corporatization," the former state-owned enterprise transforms its legal organizational form into a shareholding company. The question, of course, is who is holding the shares? In most of these corporatized firms the majority of shares are held by the State Property Agency or the newly created State Holding Corporation (ÁV-Rt). That is, as "public" and "private" actors coparticipate in the new recombinant property forms, the nature and instruments of the "public" dimension change: Whereas "state ownership" in socialism meant unmediated and indivisible ownership by a state ministry (e.g., Ministry of Industry), corporatization in postcommunism entails share ownership by one or another government agency responsible for state property.

Such corporatization mandated by a privatization agency in the current context has some distinctive features of renationalization. In the 1980s, managers in Hungary (and workers in Poland) exercised de facto property rights. Although they enjoyed no rights over disposal of property, they did exercise rights of residual control as well as rights over residual income streams. In the 1990s, corporatization paradoxically involves efforts by the state to reclaim the actual exercise of the property rights that had devolved to enterprise-level actors. Ironically, the agencies responsible for privatization are acting as agents of étatization (Voszka 1992).

The "trap of centralization" already well known in the region (Bruszt 1988) stands as a warning, however, that the effective exercise of such centralized control varies inversely with the scope and the degree of direct intervention. One encounters, therefore, proposals for privatizing the asset management function. In such programs, the state retains the right to dispose of property but delegates its rights as shareholder to private consulting firms and portfolio management teams who oversee daily operations and strategic decisions on a subcontracting or commission basis.

\section{Interenterprise Ownership}

The state is seldom, however, the sole shareholder of the corporatized firms. Who are the other shareholders of the RTs enumerated on line 2 of 
table 1 ? To answer this question, I compiled a data set on the ownership structure of the largest 200 Hungarian corporations (ranked by sales). ${ }^{9}$ These firms compose the "Top 200" of the 1993 listing of Figyelö, a leading Hungarian business weekly. Like their Fortune 500 counterparts in the United States, the Figyelö 200 firms are major players in the Hungarian economy employing an estimated $21 \%$ of the labor force and accounting for $37 \%$ of total net sales and $42 \%$ of export revenues (Figyelö 1993). The data also include the top 25 Hungarian banks (ranked by assets). Ownership data were obtained directly from the Hungarian Courts of Registry where corporate files contain not only information on the company's officers and board of directors but also a complete list of the company's owners as of the 1993 annual shareholders' meeting. The data analyzed here are limited to the top 20 shareholders of each corporation. ${ }^{10}$ In the Budapest Court of Registry and the 19 county registries, we were able to locate ownership files for 195 of the 200 corporations and for all of the 25 banks, referred to below as the "Top 220" firms.

Who holds the shares of these 220 largest enterprises and banks? I found some form of state ownership-with shares held by the ÁV-Rt, the SPA, or the institutions of local government (who had typically exchanged their real estate holdings for enterprise shares)-present in the overwhelming majority (71\%) of these enterprises and banks. More surprisingly, given the relatively short time since the "system change" in 1989-90, we found 36 companies (i.e., more than $16 \%$ of this population) in majority foreign ownership. Hungarian private individuals (summed down the top 20 owners) hold at least $25 \%$ of the shares of only 12 of these largest enterprises and banks.

Most interesting from the perspective of this article is the finding of 87 cases in which another Hungarian company is among the 20 largest shareholders. In 42 of these cases the other Hungarian companies to-

\footnotetext{
${ }^{9}$ Such data collection is not a simple matter where capital markets are poorly developed. There is no Hungarian Moody's and certainly no corporate directory equivalent to Industrial Groupings in Japan or Keiretsu no Kenkyu (see, e.g., Gerlach and Lincoln 1992). The labor-intensive solution has been to gather that data directly from the Hungarian Courts of Registry. My thanks to Lajos Vékás, professor of law, ELTE, and Rector of the Institute for Advanced Study, Collegium Budapest, for his interventions to secure access to these data and to Szabolcs Kemény and Jonathan Uphoff for assistance in data collection.

${ }^{10}$ This 20-owner limitation is a convention adopted in research on intercorporate ownership in East Asia (Gerlach and Lincoln 1992; Hoshi 1994). In the Hungarian economy where only 37 firms are traded on the Budapest stock exchange and where corporate shareholding is not widely dispersed among hundreds of small investors, the 20-owner restriction allows us to account for at least $90 \%$ of the shares held in virtually every company.
} 
gether hold a clear majority (50\% plus one share). Thus, by the most restrictive definition, almost $20 \%$ of our Top 220 companies are unambiguous cases of interenterprise ownership; and we find some degree of interenterprise ownership in almost $40 \%$ of these large companies.

Figure 1 presents two discrete networks formed through such interenterprise ownership. Arrows indicate directionality in which a given firm holds shares in another large enterprise. Weak ties (shareholdings with other firms that do not have at least one other tie, whether as owner or owned, to any other firm in the network) are not displayed. ${ }^{11}$ The relations depicted in the figure, we emphasize, are the direct horizontal ties among the very largest enterprises - the superhighways, so to speak, of Hungarian corporate networks. The diagrams presented in figure 1 indicate a different way of mapping the social space of property transformation than that suggested in table 1 . Whereas table 1 grouped entities according to their legal corporate status, here we trace not the distribution of attributes but the patterns of social ties.

In analyzing the relational dynamics of recombinant property, we now shift our focus from the corporate thoroughfares linking the large enterprises to examine the local byways linking spin-off properties within the gravitational field of large enterprises.

\section{Corporate Satellites}

We turn thus to the form with the most dramatic growth during the postsocialist period, the newly established limited liability companies (KFT), enumerated on line 3 of table 1. Some of these KFTs are genuinely private entrepreneurial ventures. But many of these limited liability companies are not entirely distinct from the transformed shareholding companies examined above. In fact, the formerly socialist enterprises have been active founders and continue as current owners of the newly incorporated units.

The basic process of this property transformation is one of decentralized reorganization: Under the pressure of enormous debt, declining sales, and threats of bankruptcy (or, in cases of more prosperous enterprises, to forestall takeovers as well as to increase autonomy from state ministries) directors of many large enterprises are breaking up their firms (along divisional, factory, departmental, or even workshop lines) into numerous joint stock and limited liability companies. It is not uncommon

\footnotetext{
${ }^{11}$ The total pattern of strong and weak ties will be examined in a later study that uses block-model analysis, tests for bank centrality, and assesses the relationship between ownership ties and director interlocks. The purpose of that study will be to identify the major corporate groupings in the Hungarian economy.
} 


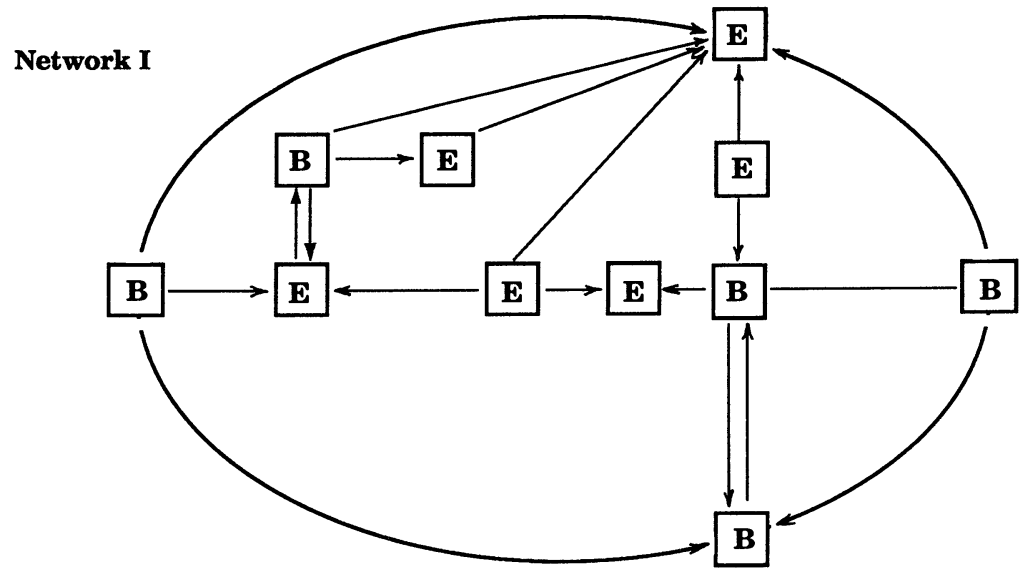

Network II

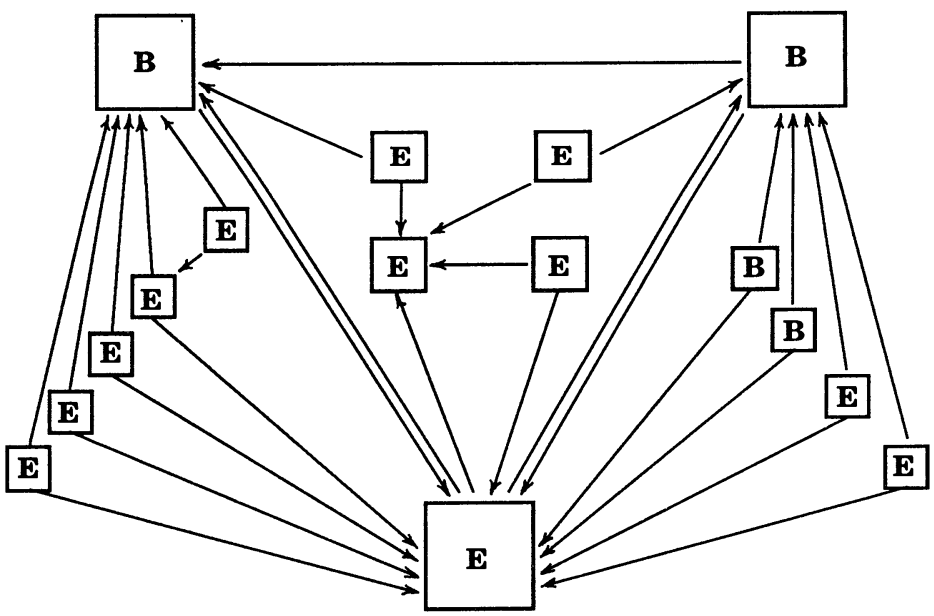

B = Financial Institution (Bank or Insurance) $\quad E=$ Enterprise

FIG. 1.-Two interenterprise ownership networks among large Hungarian firms (based on data gathered from corporate files of 200 largest enterprises and top 25 banks in Hungarian Courts of Registry). 


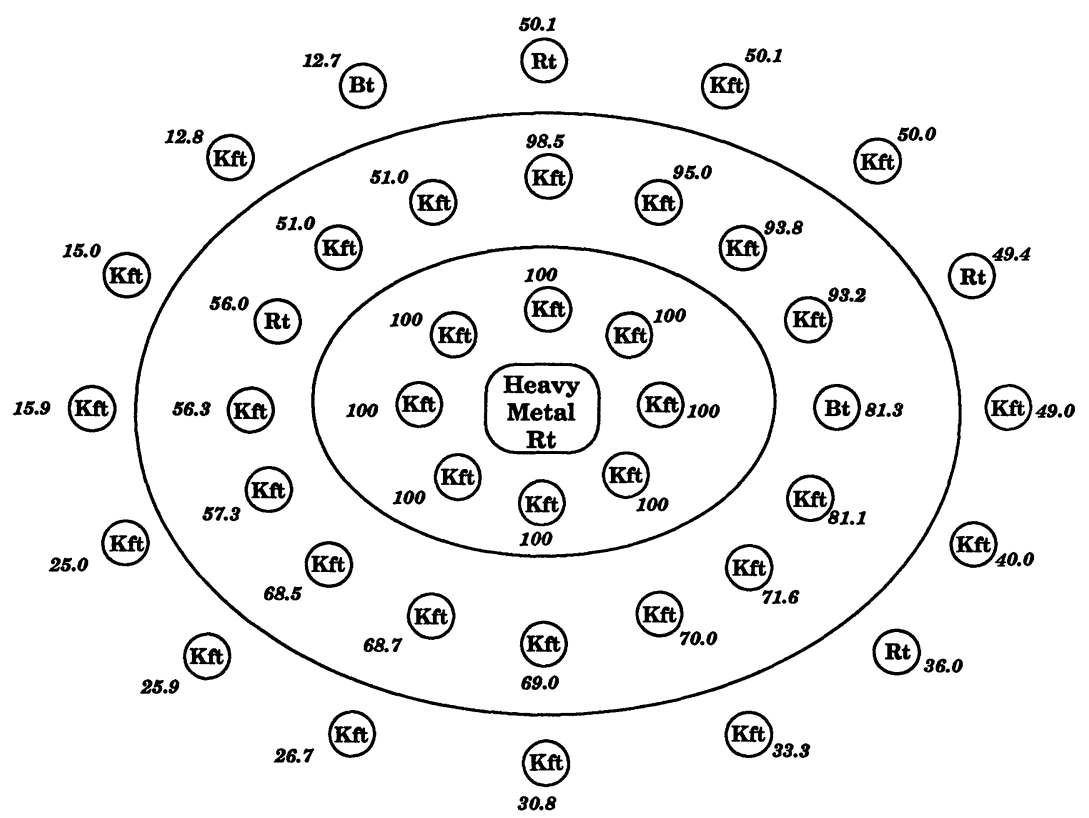

\section{Rt $=$ Shareholding Company \\ Kft = Limited Liability Company \\ Bt $=$ Partnerships \\ Numerals in italics indicate Heavy Metal's ownership stake in a given satellite.}

FIG. 2.-Corporate satellites at Heavy Metal (based on data from internal company documents).

to find virtually all of the activities of a large public enterprise distributed among 15-20 such satellites orbiting around the corporate headquarters.

As newly incorporated entities with legal identities, these new units are nominally independent-registered separately, with their own directors and separate balance sheets. But on closer inspection, their status in practice is semiautonomous. An examination of the computerized records of the Budapest Court of Registry indicates, for example, that the controlling shares of these corporate satellites are typically held by the public enterprises themselves. This pattern is exemplified by the case of one of Hungary's largest metallurgy firms represented in figure 2. As we see in that figure, "Heavy Metal," an enormous shareholding company 
in the portfolio of the State Holding Corporation, is the majority shareholder of 26 of its 40 corporate satellites.

Like Saturn's rings, Heavy Metal's satellites revolve around the giant corporate planet in concentric orbits. Near the center are the core metallurgy units, hot-rolling mills, energy, maintenance, and strategic planning units held in a kind of geosynchronous orbit by $100 \%$ ownership. In the next ring, where the corporate headquarters holds roughly $50 \%-$ $99 \%$ of the shares, are the cold-rolling mills, wire and cable production, the oxygen facility, galvanizing and other finishing treatments, specialized castings, quality control, and marketing units. As this listing suggests, these satellites are linked to each other and to the core units by ties of technological dependence. Relations between the middle-ring satellites and the company center are marked by the center's recurrent efforts to introduce stricter accounting procedures and tighter financial controls. These attempts are countered by the units' efforts to increase their autonomy-coordinated through personal ties and formalized in the biweekly meetings of the "Club of KFT Managing Directors."

The satellites of the outer ring are even more heterogeneous in their production profiles (construction, industrial services, computing, ceramics, machining) and are usually of lower levels of capitalization. Units of this outer ring are less fixed in Heavy Metal's gravitational field: some have recently entered and some seem about to leave. Among the new entrants are some of Heavy Metal's domestic customers. Unable to collect receivables, Heavy Metal exchanged interenterprise debt for equity in its clients, preferring that these meteors be swept into an orbit rather than be lost in liquidation. Among those satellites launched from the old state enterprise are some for which Heavy Metal augments its less than majority ownership with leasing arrangements to keep centrifugal forces in check.

The corporate satellites among the limited liability companies enumerated on line 3 of table 1 are, thus, far from unambiguously "private" ventures; yet neither are they unmistakably "statist" residues of the socialist past. Property shares in most corporate satellites are not limited to the founding enterprise. Top- and mid-level managers, professionals, and other staff can be found on the lists of founding partners and current owners. Such private persons rarely acquire complete ownership of the corporate satellite, preferring to use their insider knowledge to exploit the ambiguities of institutional coownership. The corporate satellites are thus partially a result of the hedging and risk-sharing strategies of individual managers. We might ask why a given manager would not want to acquire $100 \%$ ownership in order to obtain $100 \%$ of the profit, but from the perspective of a given manager the calculus instead is, "Why acquire $100 \%$ of the risk if some can be shared with the corporate cen- 
ter?" With ambiguous interests and divided loyalties, these risk-sharing (or risk-shedding) owner/managers are organizationally hedging (Sabel 1990). ${ }^{12}$

Not uncommonly, these individuals are joined in mixed ownership by other joint stock companies and limited liability companies-sometimes by independent companies, often by other KFTs in a similar orbit around the same enterprise, and frequently by shareholding companies or KFTs spinning around some other enterprise with lines of purchase or supply to the corporate unit (Voszka 1991). Banks also participate in this form of recombinant property. In many cases, the establishment of KFTs and other new corporate forms is triggered by enterprise debt. In the reorganization of the insolvent firms, the commercial banks (whose shares as joint stock companies are still predominantly state owned) become shareholders of the corporate satellites by exchanging debt for equity.

We have used the term "corporate satellite" to designate this instance of recombinant property. An exact (but cumbersome) terminology reflects the complex, intertwined character of property relations in Hungary: a limited liability company owned by private persons, by private ventures, and by other limited liability companies owned by joint stock companies, banks, and large public enterprises owned by the state. The new property forms thus find horizontal ties of cross-ownership intertwined with vertical ties of nested holdings.

\section{Metamorphic Networks}

The recombinant character of Hungarian property is a function not only of the direct (horizontal) ownership ties among the largest firms and of their direct (vertical) ties to their corporate satellites but also of the network properties of the full ensemble of direct and indirect ties linking entities, irrespective of their attributes (large, small, or of various legal forms) in a given configuration. The available data do not allow us to present a comprehensive map of these complex relations. Records in the Courts of Registry include documents on the owners of a particular firm,

${ }^{12}$ Many of these mid-level managers had experiences in the 1980s with an organizational precursor of the present recombinant forms - the intraenterprise partnerships-in which semiautonomous subcontracting units used enterprise equipment to produce goods or services during the "off hours" (Stark 1986, 1989). Like "second economy" producers who continued to hold a job in state enterprises, these intrapreneurial units were a widespread result of hedging strategies in the Hungarian economy. Some of these partnerships were scarcely disguised rent-seeking schemes that privatized profit streams and left expenses with the state-owned enterprise. Others creatively redeployed resources from diverse parts of the shop floor and regrouped, as well, the informal norms of reciprocity with the technical norms of professionals. 


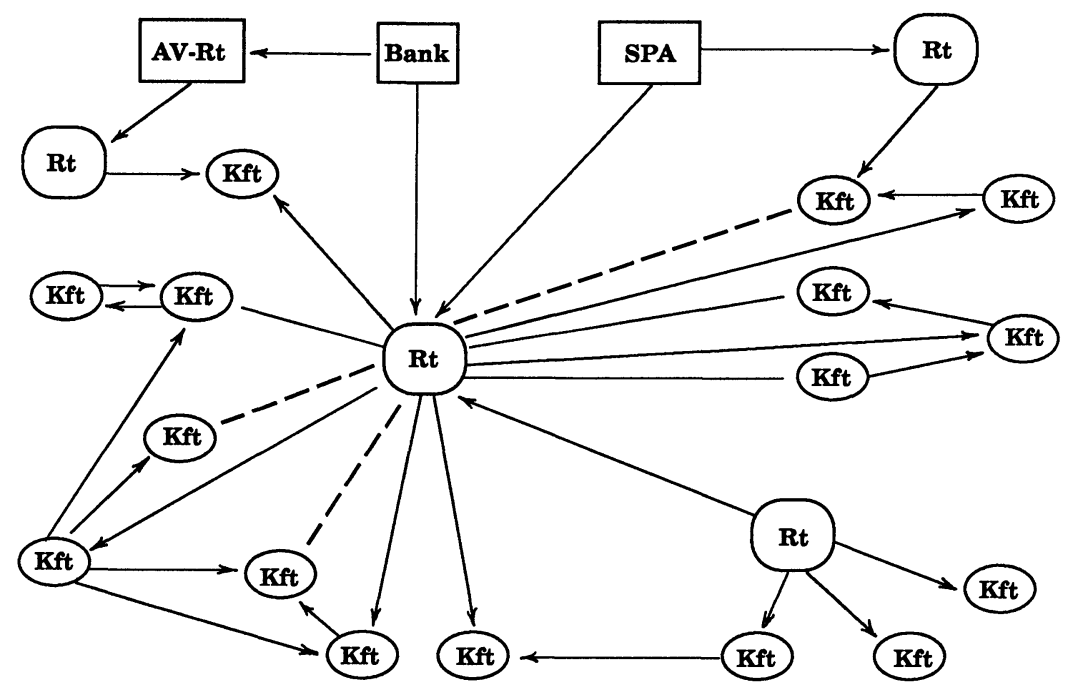

Fig. 3.-A metamorphic network (based on data from Heavy Metal internal documents, SPA files, corporate files, and the Budapest Court of Registry).

but enterprises are not required to report the companies in which they hold a stake. However, on the basis of enterprise-level field research, examination of public records at the SPA, and interviews with bankers and executives of consulting firms we have been able to reconstruct partially such networks as represented in figure 3 .

For orientation in this graphic space, we position figure 3 in relation to figures 1 and 2. Figure 1 presented interenterprise ownership networks formed through horizontal ties directly linking large enterprises. Figure 2 zoomed in on the corporate satellites of a single large enterprise. With figure 3 we pull back to examine a fragment of a broader interenterprise ownership network bringing into focus the ties that link corporate satellites to each other and that form the indirect ties among heterogeneous units in a more loosely coupled network. ${ }^{13}$

${ }^{13}$ The metamorphic network is not a simple summation of the set of horizontal and vertical ties: to categorically label the ties between a given KFT and a given RT as "vertical" would be to ignore the ways the KFTs are recombining properties. To the extent that network qualities (network properties, in the double sense of the term) are emergent in the metamorphic network, the language of horizontal and vertical should give place to more appropriate descriptors such as extensivity, density, tight or loose coupling, strong or weak ties, structural holes, and the like (Breiger and Pattison 1986; Burt 1992). 
I label this emergent form of recombinant property a metamorphic network. Here we see that the limited liability companies that began as corporate spin-offs are oriented through ownership ties either to more than one shareholding company and/or to other limited liability companies. In the metamorphic network, actors recognize the network properties of their interdependent assets and regroup them across formal organizational boundaries. These creative regroupings fail to respect the organizational boundaries between enterprises as well as the boundaries between public and private.

With few exceptions (Sabel and Prokop 1994), the literature on postsocialist property transformation (most of it confined to "privatization") assumes that the economic unit to be restructured is the individual enterprise. But the identification of interfirm networks suggests that policies and practices aimed at restructuring should target not the isolated firm but networks of firms. Such an alternative strategy of restructuring recognizes that assets and liabilities have distinctive network properties.

The industrial structure of the socialist economy commonly grouped, within a single enterprise, assets that were incompatible (except within the logic of central planning). Merely separating or simply regrouping such assets within existing enterprises alone (on a firm-by-firm basis) cannot equal the more fruitful recombinations of complementary assets across a set of firms. Restructuring via recombinant networks thus opens the possibilities of increasing the value of existing assets through their recombination. This regrouping does not necessarily imply bringing interdependent assets under the common ownership umbrella of a hierarchically organized enterprise. As such, Hungarian recombinant property provides examples of intercorporate networks as alternatives to a dichotomously forced choice between markets and hierarchies.

\section{THE CENTRALIZED MANAGEMENT OF LIABILITIES}

In the previous section, we examined the decentralized reorganization of assets. Property transformation, however, involves not only assets and rights but also liabilities and obligations. In this section, we analyze what happens in a postsocialist economy when actors are called to account for enterprise debt.

\section{Taking the Last Small Steps}

The liabilities management story begins in 1991 when the Hungarian government fundamentally modified three important laws regulating the 
accounting of assets and liabilities in an attempt to maintain its lead in regional competition for foreign investments and international credits. Hungary's comparative advantage, it appeared, was its gradualism, which, across the decades of the 1970s and 1980s, had yielded a full range of marketlike institutions. Admittedly, these were not the institutions of a market economy, but they were close; and so, the government reasoned, why not take the last small steps? As the pioneer attempt to bring postsocialist practice in full conformity with Western accounting and banking standards, the new measures could be cast as a bold move when appealing to international lending agencies. But because they were not big steps, the new measures could gain external legitimation without creating a domestic shock.

Thus, the new Accounting Law of 1991 (which took effect on January $1,1992)$ required enterprises to switch to Western-style accounting principles. The simultaneously enacted, tough new Western-style Bankruptcy Act similarly contained stiff personal penalties for directors of enterprises that failed to file for bankruptcy after the accountants (using the new accounting principles) sounded the alarm. At the same time, the new Act on Financial Institutions introduced in December 1991 was designed to put Hungary's commercial banks on a Western footing. In particular, the reserve requirements for measuring capital-adequacy ratios were modified and the securities and other financial instruments for provisioning against qualified loans were respecified.

The last small steps proved to be a leap into the abyss. Already reeling from the collapse of the CMEA (Council for Mutual Economic Assistance) markets, enterprise directors now learned from their accountants that the new accounting practices were coloring the companies' books even redder than expected. By the end of 1992, over 10,000 bankruptcies and liquidation proceedings had been initiated-a figure 10 times higher than during the previous year when enterprises had experienced the worst shock of the collapsed Eastern markets (Bokros 1994). With one-third to one-half of enterprises in the red, the loss-making firms began to stop payment on their bank credits. By the end of 1992, the overdue loan stock of the banking system was 127 billion forints $(1.5$ billion in U.S. dollars) up $90 \%$ from the previous year (National Bank of Hungary 1992, p. 109).

With thousands of firms filing for bankruptcy, the banks were forced by the new banking law to reclassify loans. The subsequent dramatic increase in the new legally required provisionings against poorly performing loans cut deeply into bank profits, slashed dividends and tax revenues from the banking sector to the state treasury, and turned the banks' capital-adequacy ratios from positive to negative. The banking 
system was in crisis-first announced, no less, in the Financial Times of London (Denton 1993).

\section{From Small Steps to Big Bailouts}

The same government that had launched an unintended financial shock now initiated a bold plan to save the banks. In its 1992 loan consolidation program, the government bought $\mathrm{Ft} 104.9$ billion (about $\$ 1$ billion) of qualified debt (almost all in the "bad" debt classification) involving 14 banks and 1,885 companies. In a related move in early 1993, the government also purchased the bank debt of 11 giant enterprises (the so-called dirty dozen) for roughly $\$ 300$ million. But the loan consolidation and enterprise recapitalization programs did not restore stability in the banking sector. By September 1993, only nine months later, financial experts were estimating that loans in arrears had once again soared to $20 \%$ of total loan portfolios. And the 10 largest banks were again hovering at or below the $0 \%$ capital-adequacy ratio (a condition of technical insolvency).

For the government, the new banking rules did not exclude bailing out banks and enterprises again and again. But the big bailout of 1993 had a new twist. Instead of buying the debt from the banks, this time the government adopted a two-stage strategy of first recapitalizing the banks and then using the banks to work out the enterprise debt. By injecting enormous sums of fresh capital into the banks, the Ministry of Finance became the dominant shareholder of the large commercial banks. The first stage of the strategy, then, could be summarized in a phrase: Do not acquire the debt, acquire the banks.

The second stage of the strategy was designed to harness the expertise of the banks to the service of the state. Because it was the banks, and not the state, that would be left holding the qualified debt, the banks would have an incentive to collect that debt, or at least the part they had not already written off their books. And they would do so, this time, not with the state as their sometime partner but with the state as their majority owner. But as Hungary's conservative-nationalist government should have learned from the earlier experience of state socialism, efforts to exercise control through direct ownership do not equal more effective state capacity. Banks have shown almost no willingness to use the consolidation funds for actively restructuring firms; and, despite the assumption that the Ministry of Finance's ownership would yield control of the banks, the government has been almost entirely ineffective in monitoring how the banks use the recapitalization funds.

The massive bailout programs were not, of course, without effects: At Ft 300 billion ( $\$ 3$ billion)-amounting to $10 \%$ of Hungarian GDP and 
$18.3 \%$ of the 1994 national budget (i.e., proportionally more than the U.S. savings and loan bailout) — the bailouts created a long queue of banks and firms with their hands out, reaching for the state's pocketbook.

Thus, at the same time that the corporate networks were engaged in the decentralized reorganization of assets, the Hungarian state attempted the centralized management of liabilities. That centralization has not left the decentralized processes untouched. From the perspective of the enterprises, "debt consolidation" triggers the organizational separation of debts from assets. The Hungarian government's attempt at the centralized management of liabilities stimulates the networks to complement their strategies of risk spreading with new strategies of risk shedding. Two types of strategies can be identified, each based on the organizational separation of assets and liabilities. In one type, assets are distributed to the satellites and debts are centralized, increasing the enterprises' chances of inclusion in the government-funded debt consolidation. In the other, assets are closely held by the enterprise center and liabilities are distributed to the satellites where network ties and political connections manipulate proceedings in a Hungarian version of "bankruptcy for profit" (Akerlof and Romer [1993] coin the term in their study of statemanaged liabilities in the U.S. savings and loan bailout).

We thus see a new paternalism in Hungary: Whereas in the state socialist economy paternalism was based on the state's attempts to centrally manage assets (Kornai 1993a), in the first years of the postsocialist economy paternalism is based on the state's attempts to centrally manage liabilities. Centralized management of liabilities will not continue indefinitely, but the organizational dynamics of enterprises formed under the new paternalistic conditions are likely to have strong path-dependent effects.

\section{THE MULTIPLE ACCOUNTS OF RECOMBINANT PROPERTY}

In the highly uncertain organizational environment that is the postsocialist economy, relatively few actors (apart from institutional designers) set out with the aim to create a market economy. Many, indeed would welcome such an outcome. But their immediate goals are more pragmatic: at best to thrive, at least to survive. And so they strive to use whatever resources are available. That task is not so simple because one must first identify the relevant system of accounting in which something can exist as a resource. At the extreme, it is sometimes even difficult to distinguish a liability from an asset. If the liabilities of your organization (enterprise or bank) are big enough, perhaps they can be translated into qualifications for more resources. And what could be more worthless 
than a bankrupted limited liability company-except, of course, if you have shed the risk to the banks (and then to the state) and put the assets in another form. Assets and liabilities have value not in themselves but in relation to legitimating principles.

To examine how economic actors in the postsocialist setting maneuver not only through an ecology of organizations but also through a complex ecology of ordering principles we need to understand the doubly associative character of assets. There are no free-floating resources. To exist as an asset a potential resource must be mobilizable through ties of association among persons (Granovetter 1985). And to be of value a potential resource must also have relative worth according to a standard of measure. To be able to circulate through the ties that bind (and thus contribute to that binding) an asset must be justified within a relatively stabilized network of categories that make up a legitimating principle (Thévenot 1985; Boltanski and Thévenot 1991; Latour 1988; White 1992). Regrouping assets thus involves making new associations-not only by rearranging social ties among persons and things but also by drawing on diverse repertoires of justificatory principles.

To emphasize the patterned and the performative aspects of this process, I exploit a notion of accounts. Etymologically rich, the term simultaneously connotes bookkeeping and narration. Both dimensions entail evaluative judgments, and each implies the other: Accountants prepare story lines according to established formulae, and in the accountings of a good storyteller we know what counts. In everyday life, we are all bookkeepers and storytellers. We keep accounts and we give accounts, and most important, we can all be called to account for our actions. When we make such an accounting, we draw on and reproduce social orders. We can competently produce justifications only in terms of established and recognized ordering principles, standards, and measures of evaluation. Because we do not simply give reasons but also have reasons for doing things, accounts are not simply retrospective; the imperative of justification (Boltanski and Thévenot 1991) structures what we do and not simply how we explain. We can never simply "calculate" because we must do so with units and instruments of measurement that are deeply structured by accounts of what can be of value. We reproduce these units of measurement and we recalibrate the measuring instruments when we assert our worthiness, when we defer to the "more worthy," or when we denounce their status according to some other standard of evaluation. When we give an account, we affirm or challenge the ordering criteria according to which our actions (and/or those of others) have been or will be evaluated. And it is always within accounts that we "size up the situation," for not every form of worth can be made to apply and not every asset is in a form mobilizable for the situation. We evaluate the 
situation by maneuvering to use scales that measure some types of worth and not others, thereby acting to validate some accounts and discredit others.

The multiple accounts of recombinant property respond to and exploit the fundamental, though diffused, uncertainty about the organizational environment. In transformative economies, firms have to worry not simply about whether there is demand for their products, or about the rate of return on their investment, or about the level of profitability but also about the very principle of selection itself. Thus, the question is not only "Will I survive the market test?"- -but also, under what conditions is proof of worth on market principles neither sufficient nor necessary to survive? Because there are multiply operative, mutually coexistent principles of justification according to which you can be called on to give accounts of your actions, you cannot be sure what counts. By what proof and according to which principles of justification are you worthy to steward such and such resources? Because of this uncertainty, actors will seek to diversify their assets, to hold resources in multiple accounts.

This ability to glide among principles and to produce multiple accountings is an organizational hedging. It differs, however, from the kind of hedging to minimize risk exposure that we would find within a purely market logic - as, for example, when the shopkeeper who sells swimwear and suntan lotion also devotes some floor space to umbrellas. Instead of acting within a single regime of evaluation, these actors use organizational hedging that crosses and combines disparate evaluative principles. Recombinant property is a particular kind of portfolio management. It is an attempt to have a resource that can be justified or assessed by more than one standard of measure (as, e.g., the rabbit breeder whose roadside stand advertises "pets and meat" in the documentary film, Roger and $M e$ ). In managing one's portfolio of justifications, one starts from the dictum: diversify your accounts.

The adroit recombinant agent in the transformative economies of East Central Europe diversifies holdings in response to fundamental uncertainties about what can constitute a resource. Under conditions not simply of market uncertainty but of organizational uncertainty, there can be multiple (and intertwined) strategies for survival-based in some cases on profitability but in others on eligibility. Where your success is judged, and the resources placed at your disposal determined, sometimes by your market share and sometimes by the number of workers you employ in a region; sometimes by your price-earnings ratio and sometimes by your "strategic importance"; and, when even the absolute size of your losses can be transformed into an asset yielding an income stream, you might be wise to diversify your portfolio, to be able to shift your accounts, to be equally skilled in applying for loans as in applying for job creation 
subsidies, to have a multilingual command of the grammar of credit worthiness and the syntax of debt forgiveness. To hold recombinant property is to have such a diversified portfolio.

To gain room for maneuver, actors court and even create ambiguity. They measure in multiple units, they speak in many tongues. They will be less controlled by others if they can be accountable (able to make credible accounts) to many. ${ }^{14}$ In so doing, they produce the polyphonic discourse of worth that is postsocialism.

We can hear that polyphonic chorus in the diverse ways that firms justify their claims for participation in the debt-relief program. The following litany of justifications are stylized versions of claims encountered in discussions with bankers, property agency officials, and enterprise directors: Our firm should be included in the debt relief program

because we will forgive our debtors (i.e., our firm occupies a strategic place in a network of interenterprise debt)

because we are truly credit worthy (i.e., if our liabilities are separated from our assets, we will again be eligible for more bank financing. Similar translations could be provided for each of the following justifications)

because we employ thousands

because our suppliers depend on us for a market

because we are in your election district

because our customers depend on our product inputs

because we can then be privatized

because we can never be privatized

because we took big risks

because we were prudent and did not take risks

because we were planned in the past

because we have a plan for the future

because we export to the West

because we export to the East

because our product has been awarded an International Standards Quality

Control Certificate

because our product is part of the Hungarian national heritage

because we are an employee buy-out

because we are a management buy-in

because we are partly state-owned

because we are partly privately held

because our creditors drove us into bankruptcy when they loaned to us at higher than market rates to artificially raise bank profits in order to pay dividends into a state treasury whose coffers had dwindled when corporations like ourselves effectively stopped paying taxes.

And so we must ask, into whose account and by which account will debt forgiveness flow? Or, in such a situation, is anyone accountable?

${ }^{14}$ See Padgett and Ansell (1993) for an analysis of such multivocality in another historical setting. 


\section{AN EAST EUROPEAN CAPITALISM?}

How are we to understand these unorthodox forms, these organizational "monsters" regrouping the seemingly incongruous? In this concluding section, we reconsider the three aspects of recombinant property (blurring of public and private, blurring of enterprise boundaries, and blurring the boundedness of legitimating principles) in terms of three underlying concepts-mixture, diversity, and complexity.

\section{Mixture}

Imagine two economies, each of equal parts public and private. In one, half the firms are fully private, half are fully public. In the other, every firm is half public, half private. Each is a "mixed economy." Yet is it likely that their dynamics will be the same? ${ }^{15}$ No two economies closely approximate the thought experiment's ideal types; but it nonetheless puts in sharp relief the question What is the mix of the postsocialist mixed economy?

My findings of corporate spin-offs and recombinant reorganization at the enterprise level, and of widespread public ownership combined with interenterprise ownership networks among the very largest enterprises, challenges the assumption, widely held on all sides of the privatization debate, that postsocialist economies can be adequately represented in a two-sector model. That analytic shortcoming cannot be remedied by more precise specification of the boundary between public and private: the old property divide has been so eroded that what might once have been a distinct boundary line is now a recombinant zone. Hungary is a postsocialist mixed economy not because of a simple dualism of wellbounded state-owned firms in one sector and privately owned firms in another but because many firms themselves exploit aspects of public and private property relations. ${ }^{16}$ What we find are new forms of property in which the qualities of private and public are dissolved, interwoven, and recombined. Property in East European capitalism is recombinant property, and its analysis suggests the emergence of a distinctively East European capitalism that will differ as much from West European capitalisms as do contemporary East Asian variants.

${ }^{15}$ In a related path dependent thought experiment: Imagine two mixed economies each with half the firms fully public and half the firms fully private. The first arrived at that sectoral mix from a starting point of only public firms. The other, from a starting point of only private firms. Are their dynamics likely to be the same?

${ }^{16}$ It was not the aim of this article to produce a definitive test of the relative weights of public, private, and recombinant zones in the postsocialist mixed economy. To do so, we will need organizational surveys, conducted in close conjunction with detailed enterprise-level field investigations to yield more refined and nuanced categories and measures. 
The concept of a postsocialist mixed economy is a useful first approximation of an East European capitalism. But its essentialist categories of "public" and "private" (and the related dualisms of "market" and "redistribution")- even when opened up to the possibility of being mixed together in the same organizational setting-may be more limiting than illuminating.

For decades, capitalism was defined vis-à-vis socialism and vice versa. Their systematic comparison enriched our understanding of both, but the "methods of mirrored opposition" and similar constructs (Stark 1986; Szelényi 1978, 1988) that worked with these dualisms are no longer fruitful. The demise of socialism challenges that analytically forced choice, and it offers an opportunity for enriching comparative institutional analysis. When we stop defining capitalism in terms of socialism, we see that, in our epoch, capitalism as a construct is only analytically interesting in the plural: capitalisms must be defined and compared vis-à-vis each other.

\section{Diversity}

Our first analytic shift, therefore, must be from the conceptual tools around the concept of mixture to those around that of diversity. Capitalisms are diverse, and that diversity is manifested in forms that cannot be adequately conceptualized as mixtures of capitalism and socialism. ${ }^{17}$ By analyzing recombinant property not only as the dissolution and interweaving of elements of public and private but also as a blurring of organizational boundaries in networks of interlocking ownership, we can escape, for example, the terms of the debate about whether the "lessons of East Asia for Eastern Europe" are the virtues of neoliberalism or of neostatism (World Bank 1993; Amsden 1994). Instead we join economic sociologists who are studying the East Asian economies from a networkcentered approach in which not markets, nor states, nor isolated firms, but social networks are the basic units of analysis (Gereffi 1994; Hamilton, Zeile, and Kim 1990; Hamilton and Feenstra 1995). In this perspective, the ability of the East Asian economies to adapt flexibly to changes in world markets rests in the interlocking ties characteristic of corporate

\footnotetext{
${ }^{17}$ My argument, thus, bears no resemblance to "third road" solutions (i.e., the mistaken notion that there could be some combination of the best features of capitalism with the best features of socialism), and it follows that I am not arguing that recombinant property is a "best way." As people living in East Central Europe have known for decades if not centuries, all the best roads to capitalism started somewhere else. I am reminded of the joke in which an Irishman in the far countryside is asked, "What's the best way to get to Dublin?" He thinks for a minute, and responds, "Don't start from here."
} 
groups (Orru, Biggart, and Hamilton 1991; Granovetter 1995), whether these be the patterns of mutual shareholding within the Japanese keiretsu (Gerlach and Lincoln 1992; Hoshi 1994); the ties of family ownership within the more vertically integrated South Korean chaebol (Kim 1991; Hamilton and Feenstra 1995); the social ties of the more horizontally integrated Taiwanese quanxiqiye "related enterprises" (Numazaki 1991); or the dense ties that transgress organizational boundaries in the "buyer-driven" and "producer-driven" networks in Hong Kong, Singapore, and elsewhere in Southeast Asia (Gereffi 1994).

These recent studies of the social embeddedness and local organizational innovation characteristic of East Asian corporate networks suggest that the strategic choice is not plans or markets, or even clans or markets, but clans for markets. Market orientation must be distinguished from market coordination: a broad variety of institutions of nonmarket coordination are compatible with high performance market orientation (Schmitter 1988; Boyer 1991; Bresser Pereira 1993). Many of the most successful forms of network coordination in East Asia, moreover, appeared to early observers as highly improbable forms whose atavistic features could not possibly survive beyond the period of postwar reconstruction from which they arose. ${ }^{18}$ Our point of departure, it should be clear, however, is not to look to Eastern Europe to find Hungarian keiretsu or Czech chaebol. Instead of searching for direct counterparts, East Asian/East European comparisons will yield new concepts when we grasp the specificity of the regional variants by explaining the differences among the various countries within a region. ${ }^{19}$

Future research must examine whether the East European corporate networks are becoming successfully oriented to the world market. But it is not too early to pose analytic dimensions along which we could assess the potential for recombinant property to contribute to economic development.

\footnotetext{
${ }^{18}$ Incongruity, in itself, neither insures survival nor condemns an organizational form to an early death. Kim's (1991) discusion of the combinatory logic of the formation of the chaebol in Korea immediately following World War II invites comparison with the formation of recombinant structures during the contemporary period of East European reconstruction.

${ }^{19}$ Stark and Bruszt (1995), e.g., compare corporate networks in Hungary and the Czech Republic. They find that Hungarian networks are formed predominantly through enterprise to enterprise links, sometimes involving banks yet absent ties between banks and intermediate-level institutions such as investment companies. In the Czech Republic, by contrast, ownership networks are formed predominantly through ties at the meso level in the cross ownership of banks and large investment funds, but direct ownership connections among enterprises themselves are rare. Whereas Hungarian networks are tightly coupled at the level of enterprises but loosely coupled at the meso level, Czech networks are loosely coupled at the level of enterprises and tightly coupled at the meso level.
} 
One starting point, ready-at-hand from the burgeoning literature on the "transitional" economies, would be to ask, Do they contribute to creative destruction? That litmus test is based on a widely held assumption that economic development will be best promoted by "allowing the selection mechanism to work" through bankruptcies of underperforming enterprises. Recombinant property would not receive an unambiguously positive score measured by this standard. Indeed, the kinds of interenterprise ownership described above are classic risk-spreading and risksharing devices that mitigate differences across firms. By dampening the performance of the stronger and facilitating the survival of the weaker firms in the interfirm networks, they might even impede creative destruction in the conventional sense.

But there is some question that a tidal wave of mass bankruptcies is a long-term cure for the postsocialist economies. With the catastrophic loss of markets to the East and with the stagnation of the economies of potentially new trading partners to the West, the depth and length of the transformational crisis in East Central Europe now exceeds that of the Great Depression of the interwar period (Kornai 1993b). In such circumstances, an absolute hardening of firms' budget constraints not only drives poorly performing firms into bankruptcy but also destroys enterprises that would otherwise be quite capable of making a high performance adjustment (see esp. Cui 1994). Wanton destruction is not creative destruction, goes this reasoning, and recombinant property might save some of these struggling but capable firms through risk-sharing networks. Along this line of reasoning, we would want to assess whether the sacrifice in allocative efficiency by retarding bankruptcy is being offset by the preservation of assets with real potential for high performance in a situation of economic recovery.

A related, but analytically separate, point is that risk spreading can be a basis for risk taking. Extraordinarily high uncertainties of the kind we see now in the postsocialist economies can lead to low levels of investment with negative strategic complementarities (as when firms forgo investments because they expect a sluggish economy based on the lack of investments by others). By mitigating disinclinations to invest, risk spreading might be one means to break out of otherwise low-level equilibrium traps. ${ }^{20}$ Firms in the postsocialist transformational crisis are like mountain climbers assaulting a treacherous face, and the networks of interenterprise ownership are the safety ropes lashing them together. Neoliberals who bemoan a retarded bankruptcy rate fail to acknowledge

\footnotetext{
${ }^{20}$ On strategic complementarities in the postsocialist economies see especially Litwack (1994). Hirschman (1958) provides the classic statement on low-level equilibrium traps and the importance of risk spreading for economic development.
} 
that there might be circumstances when this mutual binding is a precondition for attempting a difficult ascent. Along this line of reasoning, we would want to assess whether the opportunities for risk shedding in the Hungarian setting can be offset when networks (rather than "developmental states" [Evans 1992]) perform disequilibrating functions that facilitate and stimulate entrepreneurial risk taking.

Economic development in East Central Europe does require more exit (some, indeed many, firms must perish) and more entry as well. But for destruction to be creative, these deaths must be accompanied by births not simply of new organizations but of new organizational forms. Organizational forms are specific bundles of routines, and the reduction of their diversity means the loss of organized information that might be of value when the environment changes (Hannan 1986; Boyer 1991; Stark 1989, 1992). From this perspective, an economy that maximized allocative efficiency (by putting all resources in the most efficient form) would sacrifice adaptive efficiency. Socialism, in this view, failed not only because it lacked a selection mechanism to eliminate organizations that performed poorly but also because it put all its economic resources in a single organizational form - the state enterprise. Socialism drastically reduced organizational diversity and in so doing prohibited a broad repertoire of organized solutions to problems of collective action. Along this line of reasoning, an assessment of forms of recombinant property in an East European capitalism should start not by testing whether they reproduce state socialism or harbor real private property but whether they contribute to adaptive efficiency.

For the property rights school, it is not destruction (bankruptcy) nor diversity but the clarity of property rights that will yield the right set of incentives to make restructuring in the postsocialist transformation performance enhancing. Instead of reassigning property rights to an owner (an ironic legacy of an essentially Marxist notion of property), this school argues that property can be productively "dis-integrated" (Grey 1980) such that different actors can legitimately claim rights to different aspects and capacities of the same thing (Hart 1988; Comisso 1991). But however disaggregated, property rights must be clarified if accountability is to be insured. Walder (1994), the leading proponent of this perspective in the postsocialist debate, for example, shows that it is not the privatization of assets but the clarification of property rights that has contributed to the dynamism of township and village enterprises in Chinese light industry.

Along this line of reasoning, we should assess whether recombinant property is leading to well-defined property rights. The initial evidence presented in this article suggests that recombinant property would fail such a test. But from another perspective in the debate over property 
rights, the blurring of enterprise boundaries might be a viable strategy to promote organizational flexibility. On the basis of research in advanced manufacturing fields in Germany and the United States, Sabel (1990) and Kogut, Shan, and Walker (1992) demonstrate that under conditions of extreme market volatility or of extraordinarily rapid technological change, economic actors engage in hedging strategies vis-à-vis other organizations (partners or competitors) in their organizational field. When the future is highly uncertain, it is far from clear at $T 1$ whether your assets will be interdependent with mine at $T 2$. In such situations, in addition to the dualism make or buy (hierarchy or market) there is an alternative-cooperate. Kogut observes that one manifestation of such a hedging strategy is cross-ownership (not simply among purchasers and suppliers but also among competitors), and he finds dense patterns of cross-ownership among competitors in the field of microprocessing where firms cannot be certain whose standards will be the industry standards in the next round. Sabel goes even further, arguing that, in cases of extremely complex asset interdependence, it is not clear-cut property claims (however dense the cross-ownership) but an ambiguity of property claims that provides flexible adaptation to the market. Sabel's argument departs radically from the property rights school: he is claiming that actors are not assigned different rights over different aspects of an asset but are making overlapping claims on the same aspect. This is ambiguous property, not disaggregated property.

The hedging strategies and boundary blurring in postsocialist reconstruction, it seems, find counterparts in some of the technologically most highly sophisticated sectors of North American and West European capitalism. Along the dimension of this line of reasoning, we should assess whether recombinant property is, in fact, contributing to flexibility and whether any gains that might so accrue are enough to offset the possible sacrifice of accountability. We reencounter this trade-off of adaptability and accountability as we turn from the issues of organizational diversity and property rights to the problem of heterogeneous legitimating principles.

\section{Complexity}

In restructuring assets, we might say that actors are "identifying" new resources, but this would suggest that the resource was simply hidden or underutilized and only needed to be uncovered. In fact, before recombining resources, they must first redefine them. We call this ability to "recognize" the properties of persons and things organizational reflexivity. It cannot be derived from the ambiguity of property claims but is a function instead of the ambiguity of organizing principles. The key to 
adaptability in this view is not simply the diversity of types of organizations but the possibilities for cross-fertilization inside and across organizations where multiply operative legitimating principles collide-or in Harrison White's (1993) phrase, "values mate to change." 21

Some might argue, of course, that multiple orders are fine-provided that each occupies a distinctly bounded domain. Such is the model of modernity in "modernization" theory: through differentiation, each domain of society would develop as a separate autonomous subsystem with its own distinctive logic. Complexity in this view requires diversity but only as the juxtaposition of clearly bounded rationalities. Marxism, of course, has its own conception of complexity: the temporary overlap of mutually contradictory principles. Both modernization theory and Marxism are deeply grounded in the transition problematic. The noisy clash of orders is only temporary: the revolutionary moment for one, the passage to differentiated domains in the other.

If we break with this transition problem, we can escape from the impoverished conceptions of complexity in both Marxism and modernization theory. In the alternative conception offered here, complexity is the interweaving of multiple justificatory principles on the same domain space. That view, of course, shares with modernization theory the notion of distinctive domains - relatively autonomous fields of action (Bourdieu 1990). And it shares with Marxism the notion of the collision of ordering principles. But unlike modernization theory, each domain is a site of heterogeneity; and unlike Marxism, that tension is not consolidated and then released in an all-encompassing revolutionary moment. The noisy clash of orders occurs throughout the social world, and it is not transient but ongoing - punctuated by relative, localized stabilizations but never equilibrium (Latour 1988).

Postsocialist societies are entering this discordant world. To still that noisy clash by the ascendency of one accounting, with profitability as the sole metric and markets as the only coordinating mechanism, would be to duplicate the attempt of Communism, with its imposition of a unitary justificatory principle, a strict hierarchy of property forms, and a single coordinating mechanism. To replicate the monochrome with a different coloring would be to destroy the heterogeneity of organizing principles that is the basis of adaptability.

As this account of recombinant property has demonstrated, postsocialist societies are not lacking in heterogeneous organizing principles. The problem therefore is not a simple lack of accountability but an over-

${ }^{21}$ See esp. Grabher (1994) for a discussion of how rivalry of coexisting organizational forms contributes to reflexivity and adaptability. For related views on adaptability and complexity, see Landau (1969), Morin (1974), and Conrad (1983). 
abundance of accountability: An actor who, within the same domain space, is accountable to every principle is accountable to none. The adaptability of modern capitalisms rests not simply in the diversity of organizations but in the organization of diversity: enough overlap of legitimating principles across domains to foster rivalry of competing accounts within domains and enough boundedness of rationalities to foster accountability. It is not in finding the right mix of public and private but in finding the right organization of diversity to yield both adaptability and accountability that postsocialist societies face their greatest challenge.

\section{REFERENCES}

Akerlof, George A., and Paul M. Romer. 1993. "Looting: The Economic Underworld of Bankruptcy for Profit." Brookings Papers on Economic Activity 2:1-73.

Alexander, Jeffrey C. 1994. "Modern, Anti, Post, and Neo: How Social Theories Have Tried to Understand the 'New World' of 'Our Time.' " Zeitschrift für Sociologie 23:165-97.

Amsden, Alice. 1994. "Can Eastern Europe Compete by Getting the Prices Right? Contrast with East Asian Structural Reforms." Pp. 81-107 in Rebuilding Capitalism: Alternative Roads after Socialism and Dirigisme, edited by Andres Soimano, Osvaldo Sunkel, and Mario I. Blejer. Ann Arbor: University of Michigan Press.

Blanchard, Oliver Jean, Kenneth A. Froot, and Jeffrey D. Sachs. 1994. Introduction to The Transition in Eastern Europe, vol. 2. Edited by Oliver Jean Blanchard, Kenneth A. Foot, and Jeffrey D. Sachs. Chicago: University of Chicago Press.

Bokros, Lajos. 1994. "Privatization and the Banking System in Hungary." Pp. 305-20 in Privatization in the Transition Process. Recent Experiences in Eastern Europe, edited by László Samuely. Geneva: United Nations Conference on Trade and Development and KOPINT-DATORG.

Boltanski, Luc, and Laurent Thévenot. 1991. De la justification: Les économies de la grandeur. Paris: Gallimard.

Bourdieu, Pierre. 1990. The Logic of Practice, translated by Richard Nice. Stanford, Calif.: Stanford University Press.

Boyer, Robert. 1991. "Markets within Alternative Coordinating Mechanisms: History, Theory, and Policy in the Light of the Nineties." Paper presented to the Conference on the Comparative Governance of Sectors, Bigorio, Switzerland.

Breiger, Ronald L. 1995. "Social Structure and the Phenomenology of Attainment." Annual Review of Sociology 21:115-36.

Breiger, Ronald L., and Philippa E. Pattison. 1986. "Cumulated Social Roles: The Duality of Persons and Their Algebras." Social Networks 8 (3): 215-56.

Bresser Pereira, Luiz Carlos. 1993. "The Crisis of the State Approach to Latin America." Discussion paper no. 1., Instituto Sul-Norte, November.

Bruszt, László. 1988. "A centralizáció csapdája és a politikai rendszer reformalternativái" (The trap of centralization and the alternatives of reforming the political system). Medvetánc, no. 1, pp. 171-97.

Bunce, Valerie, and Mária Csanadi 1993. "Uncertainty in the Transition: PostCommunism in Hungary." East European Politics and Societies 7 (2): 240-75.

Burawoy, Michael, and Pavel Krotov. 1992. "The Soviet Transition from Socialism to Capitalism: Worker Control and Economic Bargaining in the Wood Industry." American Sociological Review 57:16-38.

Burt, Ronald. 1992. Structural Holes. Cambridge, Mass.: Harvard University Press. 


\section{American Journal of Sociology}

Comisso, Ellen. 1991. "Property Rights, Liberalism, and the Transition from 'Actually Existing' Socialism." East European Politics and Societies 5 (1): 16288.

Conrad, Michael. 1983. Adaptability. New York: Plenum Press.

Cui, Zhiyuan. 1994. "Epilogue: A Schumpeterian Perspective and Beyond." In China: A Reformable Socialism? edited by Yang Gan and Zhiyuan Cui. Oxford: Oxford University Press.

- In press. "Moebius-Strip Ownership and Its Prototype in Chinese Rural Industry." Economy and Society.

Denton, Nicholas. 1993. "Two Hungarian Banks Said to Be Technically Insolvent." Financial Times, May 20.

Evans, Peter. 1992. "The State as Problem and as Solution." Pp. 139-81 in The Politics of Economic Adjustment, edited by Stephan Haggard and Robert Kaufman. Princeton, N.J.: Princeton University Press.

Figyelö. 1993. Top 200: a legnagyobb vállalkozások (The top 200 largest enterprises). Figyelö, special issue.

Gábor, István. 1979. "The Second (Secondary) Economy." Acta Oeconomica 22 (34): 91-311.

1986. "Reformok második gazdaság, államszocializmus. A 80-as évek tapasztalatainak feljödéstani és összehasonlító gazdaságtani tanulságairól" (Reforms, second economy, state socialism: Speculation on the evolutionary and comparative economic lessons of the Hungarian eighties). Valóság, no. 6, pp. 32-48.

- 1994. "Modernity or a New Type of Duality? The Second Economy of Today." Pp. 3-21 in The Legacy of Communism in Eastern Europe, edited by János Mátyás Kovács. New Brunswick, N.J.: Transaction Books.

_. 1996. "Too Many, Too Small: Small Businesses in Postsocialist Hungary." In Restructuring Networks: Legacies, Linkages, and Localities in Postsocialist Eastern Europe, edited by Gernot Grabher and David Stark. New York: Oxford University Press.

Gereffi, Gary. 1994. "The Organization of Buyer-Driven Global Commodity Chains: How U.S. Retailers Shape Overseas Production Networks." Pp. 95-122 in Commodity Chains and Global Capitalism, edited by Gary Gereffi and Miguel Kornzeniewicz. Westport, Conn.: Praeger.

Gerlach, Michael L., and James R. Lincoln. 1992. "The Organization of Business Networks in the United States and Japan." Pp. 491-520 in Networks and Organizations, edited by Nitin Nohria and Robert G. Eccles. Cambridge, Mass.: Harvard Business School Press.

Grabher, Gernot. 1994. In Praise of Waste: Redundancy in Regional Development. Berlin: Edition Sigma.

Granovetter, Mark. 1985. "Economic Action, Social Structure, and Embeddedness." American Journal of Sociology 91:481-510.

- 1995. "Coase Revisited: Business Groups in the Modern Economy." Industrial and Corporate Change 4 (1): 93-130.

Grey, Thomas. 1980. "The Disintegration of Property." Pp. 69-85 in Property, edited by J. Rolland Pennock and John W. Chapman. New York: New York University Press.

Hamilton, Gary G., and Robert C. Feenstra. 1995. "Varieties of Hierarchies and Markets: An Introduction." Industrial and Corporate Change 4 (1): 51-91.

Hamilton, Gary G., William Zeile, and Wan-Jin Kim. 1990. "The Network Structures of East Asian Economies." In Capitalism in Contrasting Cultures, edited by S. R. Clegg and S. G. Redding. Berlin: Walter de Gruyter.

Hannan, Michael T. 1986. "Uncertainty, Diversity, and Organizational Change." Pp. 73-94 in Behavioral and Social Science: Fifty Years of Discovery. Washington, D.C.: National Academy Press. 
Hart, Oliver. 1988. "Incomplete Contracts and the Theory of the Firm." Journal of Law, Economics and Organization 4 (1): 119-39.

Hirschman, Albert. 1958. The Strategy of Economic Development. New Haven, Conn.: Yale University Press.

Hoshi, Takeo. 1994. "The Economic Role of Corporate Grouping and the Main Bank System." Pp. 285-309 in The Japanese Firm: The Sources of Competitive Strength, edited by Masahiko Aoki and Ronald Dore. London: Oxford University Press.

Kim, Eun Mee. 1991. "The Industrial Organization and Growth of the Korean Chaebol: Integrating Development and Organizational Theories." Pp. 272-99 in Business Networks and Economic Development in East and Southeast Asia, edited by Gary Hamilton. Hong Kong: University of Hong Kong, Centre of Asian Studies.

Kogut, Bruce, and Udo Zander. 1992. "Knowledge of the Firm, Combinative Capabilities, and the Replication of Technology." Organization Science 3 (3): 383-97.

Kogut, Bruce, Weijan Shan, and Gordon Walker. 1992. "The Make-or-Cooperate Decision in the Context of an Industry Network." Pp. 348-65 in Networks and Organizations, edited by Nitin Nohria and Robert G. Eccles. Cambridge, Mass.: Harvard Business School Press.

Konrad, George, and Ivan Szelényi. 1979. Intellectuals on the Road to Class Power. New York: Harcourt Brace \& Jovanovich.

Kornai, János. 1980. The Economics of Shortage. Amsterdam: North-Holland Publishing.

- 1992. "The Post-Socialist Transition and the State: Reflections in the Light of Hungarian Fiscal Problems." American Economic Review 82 (2): 1-21.

- 1993a. "The Evolution of Financial Discipline under the Postsocialist System." Kyklos 46:315-36.

- 1993b. "Transitional Recession." Discussion paper. Institute for Advanced Study/Collegium Budapest.

Laky, Teréz. 1992. "Small and Medium-Size Enterprises in Hungary." Report for the European Commission. Institute for Labour Studies, Budapest.

Landau, Martin. 1969. "Redundancy, Rationality, and the Problem of Duplication and Overlap." Public Administration Review 29 (4): 346-58.

Latour, Bruno. 1988. The Pasteurization of France. Cambridge, Mass.: Harvard University Press.

Lipset, Seymour Martin. 1990. "The Death of the Third Way." National Interest, no. 20 (Summer): $25-37$.

Litwack, John. 1994. "Strategic Complementarities and Economic Transition." Discussion paper. Institute for Advanced Study/Collegium Budapest.

Mellár, Tamás 1992. "Two Years of Privatization." Népszabadság, May 22.

Morin, Edgar. 1974. "Complexity." International Social Science Journal 26 (4): 555-82.

National Bank of Hungary. 1992. Annual Report. Budapest: National Bank of Hungary.

Nee, Victor. 1989. "A Theory of Market Transition." American Sociological Review 4 (5): $663-81$.

. 1992. "Organizational Dynamics of Market Transition: Hybrid Forms, Property Rights, and Mixed Economy in China." Administrative Science Quarterly 37:1-27.

Nelson, Richard R., and Sidney G. Winter. 1982. An Evolutionary Theory of Economic Change. Cambridge: Cambridge University Press.

Neumann, László. 1989. "Market Relations in Intra-Enterprise Wage Bargaining?" Acta Oeconomica 40:319-38.

Numazaki, Ichiro. 1991. "The Role of Personal Networks in the Making of Taiwan's Guanxigiye (Related Enterprises)." Pp. 77-93 in Business Networks and Economic 


\section{American Journal of Sociology}

Development in East and Southeast Asia, edited by Gary Hamilton. Hong Kong: University of Hong Kong, Centre of Asian Studies.

Oi, Jean C. 1992. "Fiscal Reform and the Economic Foundations of Local State Corporatism in China." World Politics 45:99-126.

Orru, Marco, Nicole Woolsey Biggart, and Gary G. Hamilton. 1991. "Organizational Isomorphism in East Asia." Pp. 361-89 in The New Institutionalism in Organizational Analysis, edited by Walter W. Powell and Paul J. DiMaggio. Chicago: University of Chicago Press.

Padgett, John F., and Christopher K. Ansell. 1993. "Robust Action and the Rise of the Medici, 1400-1434." American Journal of Sociology 98:1259-1319.

Pistor, Katharina, and Joel Turkewitz. 1994. "Coping with Hydra State Ownership after Privatization: A Comparative Study of Hungary, Russia, and the Czech Republic." Presented to the Conference on Corporate Governance in Central Europe and Russia, the World Bank, December.

Róna-Tas, Ákos. 1994. "The First Shall Be Last? Entrepreneurship and Communist Cadres in the Transition from Socialism." American Journal of Sociology 100: 40-69.

Sabel, Charles. 1990. "Möbius-Strip Organizations and Open Labor Markets: Some Consequences of the Reintegration of Conception and Execution in a Volatile Economy." Pp. 23-54. in Social Theory for a Changing Society, edited by Pierre Bourdieu and James Coleman. Boulder, Colo., and New York: Westview Press and Russell Sage Foundation.

Sabel, Charles, and Jane E. Prokop. 1994. "Stabilization through Reorganization? Some Preliminary Implications of Russia's Entry into World Markets in the Age of Discursive Quality Standards." Conference on Corporate Governance in Central Europe and Russia, World Bank, December.

Sabel, Charles, and David Stark. 1982. "Planning, Politics, and Shop-Floor Power: Hidden Forms of Bargaining in Soviet-Imposed State-Socialist Societies." Politics and Society 11:439-75.

Sabel, Charles, and Jonathan Zeitlin. 1996. "Stories, Strategies, Structures: Rethinking Historical Alternatives to Mass Production." In Worlds of Possibility: Flexibility and Mass Production in Western Industrialization, edited by C. Sabel and J. Zeitlin. Cambridge: Cambridge University Press.

Schmitter, Philippe. 1988. "Modes of Governance of Economic Sectors." Manuscript. Stanford University.

Schumpeter, Joseph A. 1934. The Theory of Economic Development. Cambridge, Mass.: Harvard University Press.

Sik, Endre. 1992. "From Second Economy to Informal Economy." Journal of Public Policy 12 (2): 153-75.

Staniszkis, Jadwiga. 1991. "Political Capitalism' in Poland." East European Politics and Societies 5:127-41.

- 1993. "Ontology, Context and Chance: Three Exit Routes from Communism." Working Papers on Central and Eastern Europe, no. 31. Harvard University, Center for European Studies.

Stark, David. 1986. "Rethinking Internal Labor Markets: New Insights from a Comparative Perspective." American Sociological Review 51:492-504.

- 1989. "Coexisting Organizational Forms in Hungary's Emerging Mixed Economy." Pp. 137-68 in Remaking the Economic Institutions of Socialism: China and Eastern Europe, edited by Victor Nee and David Stark. Stanford, Calif.: Stanford University Press.

1990. "Work, Worth, and Justice." Central and East Europe Working Paper, no. 5. Harvard University, Center for European Studies.

1992. "Path Dependence and Privatization Strategies in East Central Europe." East European Politics and Societies 6:17-51. 
Stark, David, and László Bruszt. 1995. "Restructuring Networks in the Postsocialist Economic Transformation." Cornell Working Papers on Transitions from State Socialism, no. 95.4. Cornell University, Einaudi Center for International Studies.

Stark, David, and Victor Nee. 1989. "Toward an Institutional Analysis of State Socialism." Pp. 1-31 in Remaking the Economic Institutions of Socialism: China and Eastern Europe, edited by Victor Nee and David Stark. Stanford, Calif.: Stanford University Press.

Szelényi, Ivan. 1978. "Social Inequalities in State Socialist Redistributive Economies." Theory and Society 1-2:63-87.

- 1988. Socialist Entrepreneurs. Madison: University of Wisconsin Press.

1994. "Socialist Entrepreneurs-Revisited." Working Paper no. 4. University of Michigan, International Institute.

Szücs, Jenö. 1985. Les trois Europes. Paris: Harmattan.

Thévenot, Laurent. 1985. "Rules and Implements: Investment in Forms." Social Science Information 23 (1): 1-45.

Voszka, Éva 1991. "Homályból homályba. A tulajdonosi szerkezet a nagyiparban" (From twilight to twilight: Property changes in large industry). Társadalmi Szemle, no. 5 , pp. 3-12.

1992. "Escaping from the State, Escaping to the State." Paper presented at the Arne Ryde Symposium on the "Transition Problem." Rungsted, Denmark, June.

Walder, Andrew. 1994. "Corporate Organization and Local Government Property Rights in China." Pp. 53-66 in Changing Political Economies: Privatization in Post-Communist and Reforming Communist States, edited by Vedat Milor. Boulder, Colo.: Lynne Rienner.

Webster, Leila. 1992. "Private Sector Manufacturing in Hungary: A Survey of Firms." Manuscript. World Bank, Industry Development Division.

White, Harrison C. 1992. Identity and Control: A Structural Theory of Social Action. Princeton, N.J.: Princeton University Press.

. 1993. "Values Come in Styles, Which Mate to Change." Pp. 63-91 in The Origins of Values, edited by Michael Hechter, Lynn Nadel, and Richard E. Michod. New York: Aldine de Gruyter.

World Bank. 1993. The East Asian Miracle: Economic Growth and Public Policy. Oxford: Oxford University Press. 